\title{
High Sequence Variability in the Mitochondrial DNA Control Region of the Japanese Flounder Paralichthys olivaceus
}

\author{
Tetsuo Fujii ${ }^{* 1}$ and Mutsumi Nishida*2 \\ *1Japan Sea National Fisheries Research Institute, Niigata 951, Japan \\ ${ }^{*}$ Department of Marine Bioscience, Faculty of Biotechnology, Fukui Prefectural University, \\ Obama, Fukui 917, Japan
}

(Received March 3, 1997)

\begin{abstract}
The control region of mitochondrial DNA, known to be the most variable in the genome, was analyzed so as to assess its suitability for examining genetic variability and population structure in the Japanese flounder. A total of 424 nucleotide sites, including the proline transfer RNA gene and the first half of the control region, was sequenced from 55 specimens from Niigata, Honshu and Sado Island, off the north-western coast of Honshu. Out of 350 nucleotide sites on the control region, $126(36.0 \%)$ were variable, 54 haplotypes being found. Differences between nucleotide sequences ranged between 0 and $8.3 \%$ with an average (= nucleotide diversity) of $4.33 \%$, indicating that the control region of the mitochondrial DNA in the Japanese flounder is characterized by extremely high variability. The frequency in occurrence of specific nucleotides in 2 sites in the Niigata sample differed significantly from that in the Sado Island sample. This result accorded with previous studies which suggested Japanese flounder populations in Niigata and Sado belong to different local populations.
\end{abstract}

Key words: mitochondrial DNA, control region, nucleotide sequence, genetic variability, population, Japanese flounder

The Japanese flounder Paralichthys olivaceus is known to occur along the coasts of Japan, Korea and China, being most common off the north-western coast of Japan, ${ }^{1,2)}$ and is one of the most important species for the coastal fisheries in Japan, with approximately 7,000 metric tons taken annually. In recent years, however, the catch has been declining and investigation of the structure of local populations is required for stock management of the species. Earlier attempts to assess the population structure of the Japanese flounder, using allozyme analyses, had not found any genetic population differentiation possibly because of the lack of sufficient genetic polymorphisms. ${ }^{3)} \mathrm{Re}-$ cently, mitochondrial DNA (mtDNA) has been used in population studies because of its compactness, almost total maternal inheritance and fast evolutionary rate compared to nuclear DNA. ${ }^{4-6)}$ The highest rates of base substitutions and insertion/deletion events in mtDNA have been found in the first half of the control region (adjacent to the proline transfer RNA gene), probably because of reduced functional constraints. ${ }^{7-10)}$ Therefore, population studies of fishes have focused on sequences in the control region. ${ }^{11,12)}$

Sequencing of the mtDNA control region of Japanese flounder from the north-western coast of Honshu, Japan was performed so as to examine its variability. Sequences from samples which have been considered to belong to different local populations were compared and the suitability of the sequence data for stock structure analysis of this species was examined.

\section{Materials and Methods}

\section{DNA Samples}

A total of 55 Japanese flounder from two locations were used in this study. Thirty-five individuals were collected off Igarashi-hama, Niigata City, Honshu, and 20 individuals from Mano Bay, western side of Sado Island (Fig. 1). Total genomic DNA was prepared from $10-20 \mathrm{mg}$ of frozen muscle tissue from each specimen by overnight proteinase-K digestion at $37^{\circ} \mathrm{C}$, followed by purification through phenol-chloroform extractions ${ }^{13)}$ and Microcon ${ }^{\mathrm{TM}}-100$ (Amicon Inc.) purification, or by a simplified extraction method using Chelex ${ }^{\mathrm{TM}} 100$ (Bio-Rad laboratories Inc.). ${ }^{14,15)}$

\section{Amplification}

The region of mtDNA amplified by the polymerase chain reaction (PCR) was approximately 550 base pairs (bp) long and comprised part of the $\mathrm{tRNA}^{\mathrm{Thr}}$ gene, the tRNA $^{\text {Pro }}$ gene, and the first half of the control region. The forward primer $\mathrm{L} 15924^{15)}$ is located in the tRNA ${ }^{\mathrm{Thr}}$ gene, and the reverse primer $H 16498^{17}$ near the middle of the control region. For amplification, the following reagents were added to each microtube: $1 \mu l$ of template DNA, 2.5 $\mu l$ of $10 \times$ buffer $(100 \mathrm{mM}$ Tris- $\mathrm{HCl} \mathrm{pH} 8.3,30 \mathrm{mM} \mathrm{MgCl}$, $500 \mathrm{mM} \mathrm{KCl}), 2.5 \mu \mathrm{l}$ of each primer $(5 \mu \mathrm{M}), 2.5 \mu l$ of $2 \mathrm{mM}$ of each dNTP, and 0.6 unit of Thermus aquaticus (Taq) DNA polymerase. Each sample was brought up to $25 \mu \mathrm{l}$ with sterile deionized $\mathrm{H}_{2} \mathrm{O}$. PCR conditions consisted of 30-35 cycles of denaturation $\left(94^{\circ} \mathrm{C}, 40 \mathrm{sec}\right.$.), annealing $\left(45^{\circ} \mathrm{C}, 60 \mathrm{sec}.\right)$ and extension $\left(72^{\circ} \mathrm{C}, 60 \mathrm{sec}.\right)$. Amplified 


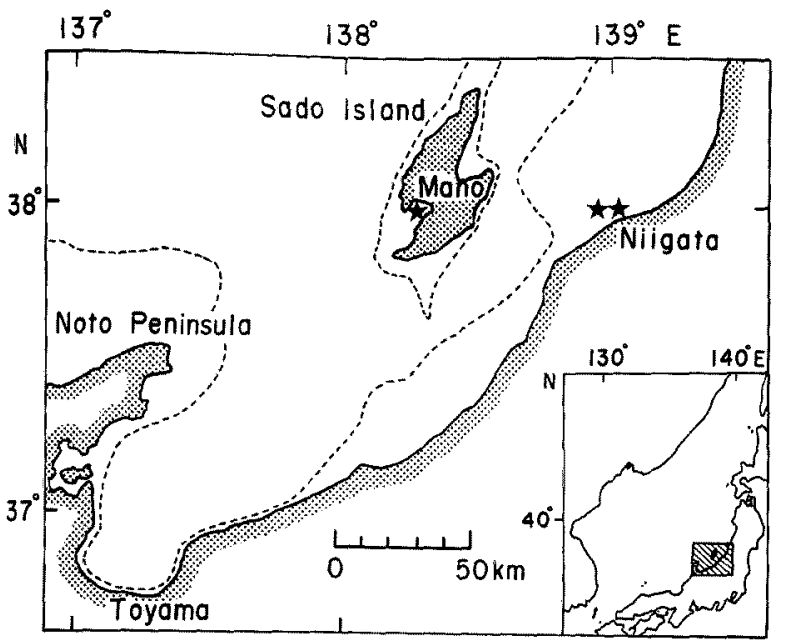

Fig. 1. Sampling locations for Japanese flounder ( $\star$, Mano Bay, Sado Island and $\star \star$, Igarashi-hama, Niigata City) in the northwestern coast of Japan.

Dotted line indicates the $200 \mathrm{~m}$ contour.

DNA products were retrieved by Microcon ${ }^{\mathrm{TM}}-100$ purification.

\section{Sequencing}

Amplified DNA was sequenced on an automated DNA sequencer (Perkin-Elmer Co. Model 373A), using the Taq Dye Deoxy ${ }^{\mathrm{TM}}$ Terminator Cycle Sequencing kit (Perkin-Elmer Co.). Sequencing was performed with the amplification primers and additional internal primers (forward and reverse), designed after the determined sequence (M. Nishida: Fukui Pref. Univ. and T. Ohkawa: Kyoto Univ., unpubl. data). The two internal primers used were PoDL1 (5'-GTAAGCATTCAGTCCGATGT-3') and PoD-H1 (5'-CGGTGTAAA GTTTCGATTAGT-3'). After the cycle-sequencing reactions, unincorporated dye terminators were removed by the CTAB (cetry-trimethyl ammonium bromide) precipitation method. The sample was resuspended in $4 \mu \mathrm{l}$ formamid loading buffer, denatured, and loaded on to the sequencer.

\section{Sequence Analysis}

Sequences were determined from the results using forward and reverse primers, and internal primers if necessaIy. Once determined, they were confirmed by comparison with the carp sequence. ${ }^{18)}$ A total of 55 sequence data were aligned so as to detect variations. Sequence differences were calculated with PAUP Ver.3.0s. ${ }^{19)}$ The frequency differences in occurrence of a specific nucleotide between the Niigata and Sado Island samples were tested with Fisher's exact probability test at each hypervariable site (at which the frequency of the dominant nucleotide was less than $90 \%$ in at least one sample).

\section{Results}

The segments (total length $550 \mathrm{bp}$ ) were amplified after PCR and 424 bp sequenced unambiguously. Comparison with the sequence from the carp ${ }^{18)}$ verified that the ob-

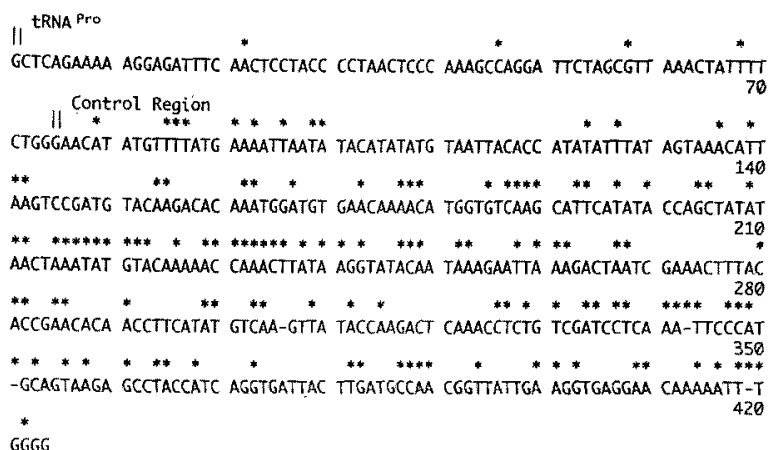

Fig. 2. Sequence for $424 \mathrm{bp}$ of mtDNA, type Sado-1, from the Japanese flounder.

The sequence shown is for the light strand. Asterisksmark the 130 variable sites found in mtDNA sequence from 54 haplotypes $(55$ individuals). Boundaries of three regions of the genome are indicated.

tained sequence included the entire tRNA ${ }^{\text {Pro }}$ gene $(74 \mathrm{bp})$ and the first half of the control region ( $350 \mathrm{bp}$; Fig. 2).

Of the $74 \mathrm{bp}$ of the tRNA ${ }^{\mathrm{P}_{\mathrm{T}}}$ gene, 4 sites $(5.4 \%)$ were variable, with only transitions being detected. In contrast, 126 sites $(36.0 \%)$ in the control region were variable. Transitions, transversions, both transitions and transversions, and single base pair insertion/deletion events were observed at 88, 10, 22 and 6 sites, respectively (Fig. 3). The frequency of variable sites in the control region was more than six times that in the tRNA ${ }^{\mathrm{Pro}}$ gene. An extremely high frequency of variable sites $(>40 \%)$ was detected at positions $100-175$ and $250-275$. The region between positions 25 and 75 was, by contrast, rather conserved $(<15 \%$, Fig. 4).

Pairwise sequence differences were also found to be high as 0 to $8.3 \%$ with an average (=nucleotide diversity ${ }^{20)}$ ) of $4.33 \%$, reflecting the abundance of variable sites. These in the control region were somewhat higher in the Sado Island samples (2.0 to $7.4 \%$; average, $4.90 \%$ ) than in the Niigata samples ( 0 to $8.0 \%$; average, $3.96 \%$ ). Values between the two samples ranged from 0.9 to $8.3 \%(4.49 \%$ on average), with a net sequence difference of $0.06 \%$ (Table 1 ).

Of the 126 variable sites in the control region, 31 were hypervariable (Table 2). The composition of nucleotides at the hypervariable sites suggested a pattern in the base substitutions. Transversions were dominant between positions 130 and 162 , where an extremely high frequency of variable sites was detected (Fig. 4). A-G transitions were dominant between positions 186 and 194, adjacent to the transversion-dominant zone. T-C transitions were dominant between position 226 and 274 (Table 2).

As shown in Table 2, positions 13, 155 and 309 were found to vary only in the Sado Island samples. Fisher's exact probability test showed that the frequency of specific nucleotides between the Sado Island and Niigata samples differed significantly $(P<0.01)$ at 4 sites (positions 13, 155, 299 and 309). Calculated $P$ values were especially small at 2 sites, $2.64 \times 10^{-5}$ at position 155 and $7.20 \times 10^{-5}$ at position 299 , with corrected $P$ values (based on the total number of variable sites, 126) being less than 0.01 . 


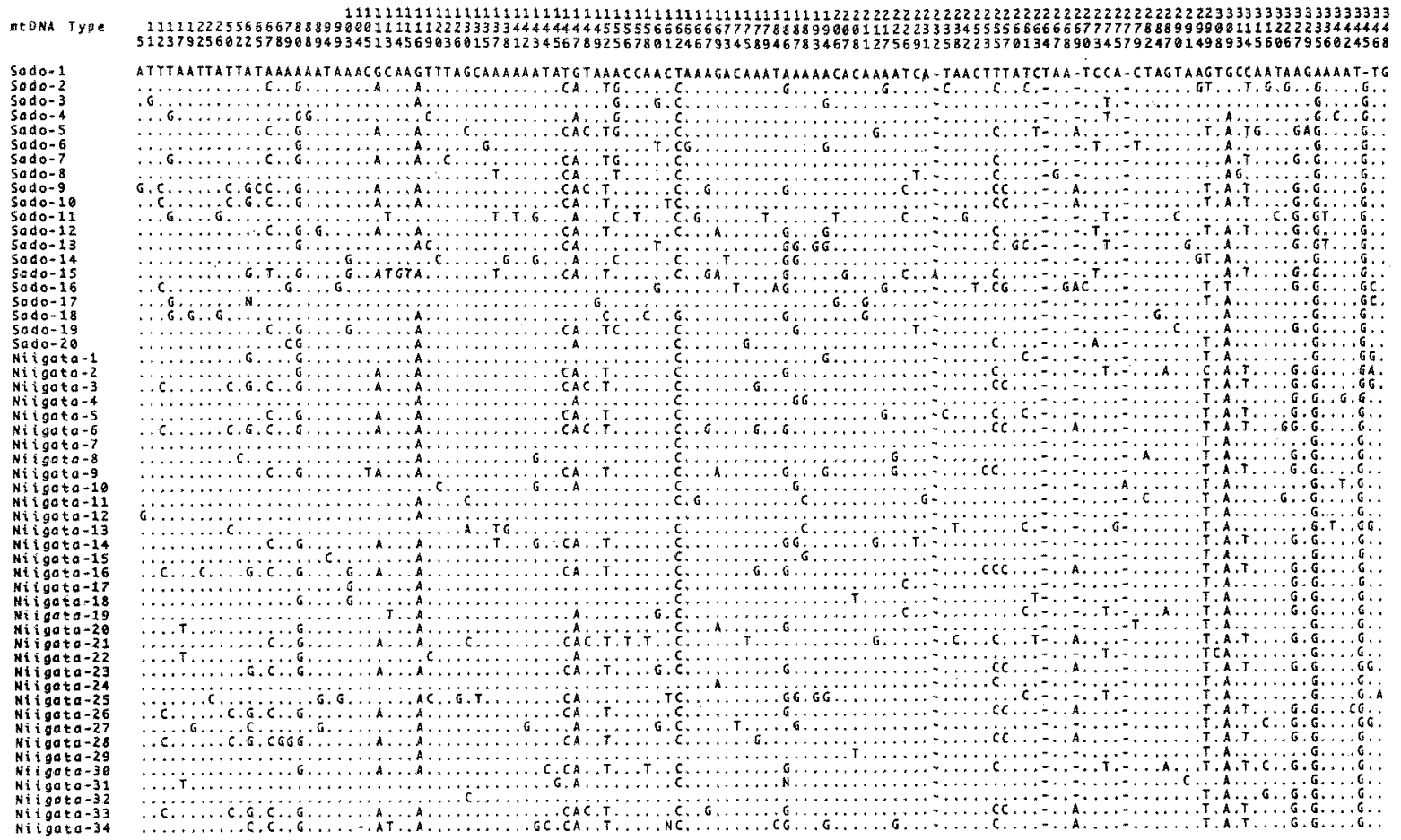

Fig. 3. Variable sites in the first half of the mtDNA control region of 54 haplotypes of the Japanese flounder.

Listed across the top are 126 variable sites numbered from the beginning of the control region. The nucleotide at each variable site in type Sado1 is given, with differing nucleotides only being indicated for other haplotypes. Dashes denote deletions relative to other sequences; and $\mathrm{N}$ indicates undetermined sites.

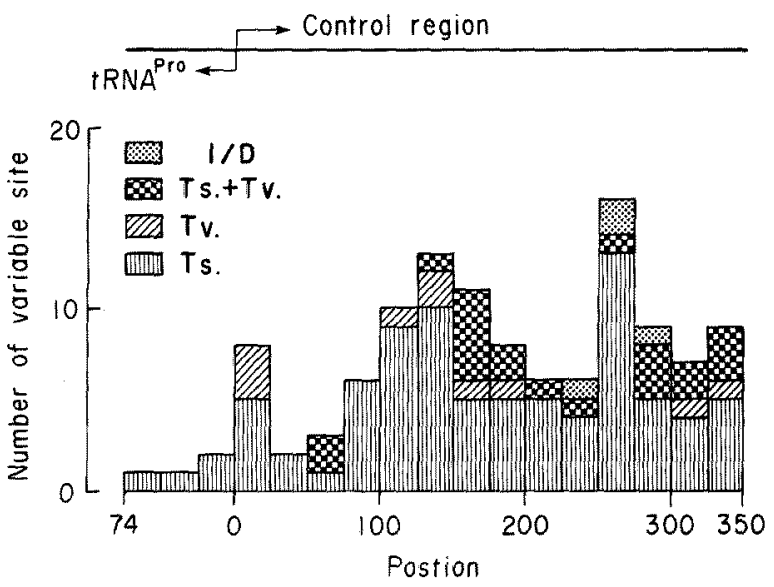

Fig. 4. Base-substitution variability as a function of position in the tRNA ${ }^{\text {Pro }}$ and first half of the control region for 54 haplotypes of the Japanese flounder.

Ts., transitions; Tv., transversions; Ts. + Tv., both transitions and transversions; I/D, insertion/deletion events.

\section{Discussion}

The most notable finding in the present study is the possession by Japanese flounder of extremely high variability in the mtDNA control region sequence. A total of 54 haplotypes were found in the 55 individuals examined.
Table 1. mtDNA sequence differences in $350 \mathrm{bp}$ of the first half of the control region based on pairwise comparisons between individuals

\begin{tabular}{ccc}
\hline & Sado Island & Niigata \\
\hline Sado Island & $4.90 \pm 1.27$ & $4.49 \pm 1.42$ \\
& $(2.0-7.4)$ & $(0.9-8.3)$ \\
Niigata & 0.06 & $3.96 \pm 1.54$ \\
& & $(0-8.3)$
\end{tabular}

Intra- and inter-locational values (mean \pm standard deviation, ranges in parentheses) are shown on and above the diagonal, respectively. The net sequence difference between the two samples is shown under the diagonal

The frequency of variable sites in the first half of the control region in the Japanese flounder $(36.0 \%)$ was greater than that reported for any other fish species; the frequency was only $0.4 \%$ in the chum salmon (Oncorhynchus keta) ${ }^{(2)}$ and between 1.35 and $2.4 \%$ in individual cichlid species. ${ }^{21}$ In fact, the present value was as high as that for twelve intergeneric species of cichlid fishes. ${ }^{16)}$ Pairwise sequence differences in the Japanese flounder individuals were also high, being equal to interspecific differences between closely related cichlid fishes..$^{16,17,21)}$ It has been reported that the evolutionary rates of protein coding genes in fish mtDNA are slow compared with mammals. ${ }^{13,22-25)}$ However, in the first half of the control region of the Japanese flounder, the frequency of variable sites was about three times higher than in the kangaroo rat (Dipodomys panamintinus) and house mouse (Mus domesticus), and 1.5 times 
Table 2. The numbers of each nucleotide at each hypervariable site and the significance of the frequency difference of specific nucleotides between Sado Island and Niigata samples calculated by Fisher's exact probability test

\begin{tabular}{|c|c|c|c|c|c|c|c|c|c|c|c|}
\hline \multirow{2}{*}{ Position } & \multicolumn{5}{|c|}{ Sado Island } & \multicolumn{5}{|c|}{ Nigata } & \multirow{2}{*}{ Significance } \\
\hline & A & $\mathrm{G}$ & $\mathrm{C}$ & $\mathrm{T}$ & - & $\mathbf{A}$ & G & $C$ & $\mathbf{T}$ & - & \\
\hline 12 & & & 3 & 17 & & & & 6 & 29 & & \\
\hline 13 & & 5 & & 15 & & & & & 35 & & ** \\
\hline 50 & & & 2 & 18 & & & & 6 & 29 & & \\
\hline 62 & 17 & 3 & & & & 24 & 9 & 2 & & & \\
\hline 67 & 12 & & 7 & 1 & & 23 & & 12 & & & \\
\hline 81 & 9 & 11 & & & & 16 & 19 & & & & \\
\hline 103 & 17 & 3 & & & & 32 & 3 & & & & \\
\hline 111 & 7 & 13 & & & & 14 & 21 & & & & \\
\hline 116 & 13 & 7 & & & & 29 & 6 & & & & \\
\hline 130 & & 19 & 1 & & & 1 & 31 & 3 & & & \\
\hline 143 & 18 & 2 & & & & 31 & 4 & & & & \\
\hline 146 & & & 10 & 10 & & & & 15 & 20 & & \\
\hline 147 & 14 & 6 & & & & 22 & 13 & & & & \\
\hline 148 & & & 2 & 18 & & & & 4 & 31 & & \\
\hline 152 & 11 & & 1 & 8 & & 21 & & & 14 & & \\
\hline 155 & 11 & 5 & 3 & 1 & & 35 & & & & & $* * *$ \\
\hline 160 & 16 & 2 & & 2 & & 32 & 3 & & & & \\
\hline 162 & & 1 & 15 & 4 & & & & 31 & 4 & & \\
\hline 186 & 12 & 8 & & & & 22 & 12 & & & & \\
\hline 187 & 17 & 3 & & & & 30 & 5 & & & & \\
\hline 194 & 16 & 4 & & & & 30 & 5 & & & & \\
\hline 226 & & & 3 & 17 & & & & 2 & 33 & & \\
\hline 255 & & & 11 & 9 & & & & 14 & 21 & & \\
\hline 257 & & 1 & 2 & 17 & & & & 7 & 28 & & \\
\hline 261 & & & 2 & 18 & & & & 6 & 29 & & \\
\hline 269 & 4 & & & & 16 & 8 & & & & 27 & \\
\hline 274 & & & 14 & 4 & & & & 30 & 5 & & $* * *$ \\
\hline 299 & & 11 & & 9 & & & 1 & 1 & 33 & & \\
\hline 309 & 15 & 4 & & 1 & & 35 & & & & & $* *$ \\
\hline 314 & & & 13 & 7 & & & & 21 & 14 & & \\
\hline 327 & 10 & 10 & & & & 14 & 21 & & & & \\
\hline
\end{tabular}

${ }^{* *} P<0.01$

${ }^{* * *} P<0.001$

Dashes denote deletions.

higher than in human. Pairwise sequence difference observed in this study was double that of the kangaroo rat, house mice, and human..$^{9,26,27)}$

There are two possible explanations for this observation of high sequence variability in Japanese flounder. Theoretically, the level of genetic variability held in a population tends to be positively correlated with the effective population size. Thus, one possibility is that this species might have continued having large population size and the high sequence variability has been maintained in it. Indeed, Japanese flounder is distributed widely around Japan; over 1 million individuals have been landed in a single year in Niigata Prefecture alone. In addition, it is considered that the population size of ground fish is more stable than that of pelagic fish in general. It is plausible that Japanese flounder may have existed in large populations in a rather stable sea environment for a long period of time compared with freshwater fish and terrestrial mammals. Alternatively, but not exclusively to the above possibility, the se- quence of the flatfishes' mtDNA control region may evolve faster than that of other vertebrates. The mtDNA control region of flatfishes is known to show very specific evolution, namely, length variation in the latter half caused by tandem duplication of a particular sequence unit, ${ }^{10)}$ and the length of the control region in Japanese flounder varies similarly. ${ }^{28), * 3}$ This peculiarity in the mtDNA control region might be related with high sequence variability in this region of the flatfishes, by allowing the region to vary very freely.

The frequency of occurrence of specific nucleotides at some sites in the mtDNA control region in Japanese flounder was significantly different between the Sado Island and Niigata samples. Japanese flounder inhabit shelf waters shallower than $150 \mathrm{~m}$, whereas Sado Island is surrounded by waters deeper than $200 \mathrm{~m}$ (Fig.1). From the ecological information and tagging studies, the population around Sado Island has been considered to be separated from those along Honshu. ${ }^{29)}$ This separation may have resulted in the genetic differences observed between them. Japanese flounder spawn pelagic eggs, larvae undergoing a planktonic life for one or two months before settling on the bottom. ${ }^{30,31)}$ Along the north-western coast of Japan, eggs and larvae could be transported by the Tsushima Current, which flows from the southwest to the northeast. Mano Bay, Sado Island faces west, enabling direct recruitment of larvae from the western areas beyond the Noto Peninsula. In fact, Japanese flounder larvae have been collected in the open water column between the Noto Peninsula and Sado Island. ${ }^{* 4}$ This recruitment mechanism, together with a low level of gene flow across the Sado Channel, might also account for the genetic difference between the Sado Island and Niigata populations. Further extensive analyses should provide useful data for stock structure of the species.

In recent years, artificially raised juvenile Japanese flounder have been released around Japan. Because the artificially raised stocks are very inferior to wild stocks in their genetic variability, ${ }^{* 5}$ probably due to the restricted number of parents used, they may be harmful genetically to wild flounders from the point of view of ensuring reproduction. Consequently, monitoring of genetic variability should also be undertaken.

Acknowledgments We thank W. Anzawa for the provision of some Japanese flounder samples, and also T. Ohkawa, H. Morita, A. Kawaguchi, M. Yamaguchi and T. Goto for helpful advice and discussion. M. Tanaka, T. Minami and $H$. Sudo provided useful comments, which were much appreciated.

\section{References}

1) M. Okiyama: Study on the early life history of a flounder, Paralichthys olivaceus (TEMMINCK et SCHLEGEL)-I. Descriptions of postlarvae. Bull. Japan Sea Reg. Fish. Res. Lab., 17, 1-12 (1967).

2) M. Tanaka, T. Goto, M. Tomiyama, and H. Sudo: Immigration, settlement and mortality of flounder (Paralichthys olivaceus) larvae and juveniles in a nursery ground, Shijiki Bay, Japan. Neth. J. Sea Res., 24, 57-67 (1989).

\footnotetext{
*1 T. Fujii et al.: Abst. Metg. Japan Soc. Fisheries Sci., April, 1996, p. 82 (in Japanese).

* T. Goto: Abst. Metg. Japan Soc. Fisheries Sci., April, 1996, p. 50 (in Japanese).

's. Fujii and M. Nishida: Abst. Metg. Japan Soc. Fisheries Sci., October, 1996, p. 92 (in Japanese).
} 
3) Y. Fujio, N. Sasaki, M. Sasaki, and A. Koganezawa: Genetic aspects of natural and released populations of plaice. Bull. Tohoku Reg. Fish. Res, Lab., 47, 51-57 (1985).

4) W. M. Brown, M. George, Jr, and A. C. Wilson: Rapid evolution of animal mitochondrial DNA. Proc. Natl. Acad. Sci. USA, 76, 1967-1971 (1979).

5) W. M. Brown, E. M. Prager, A. Wang, and A. C. Wilson: Mitochondrial DNA sequences of primates: Tempo and mode of evolution. I. Mol. Evol., 18, 225-239 (1982).

6) A. C. Wilson, R. L. Cann, S. M. Carr, M. George, U. B. Gyllensten, K. M. Helm-Bychowski, R. G. Higuchi, S. R. Palumbi, E. M. Prager, R. D. Sage, and M. Stoneking: Mitochondrial DNA and two perspectives on evolutionary genetics. Biol. J. Linn. Sci. 26, 375-400 (1985).

7) W. M. Brown: The mitochondorial genome of animals, in "Molecular Evolutionary Genetics” (ed. by R. J. Macintyre), Plenum Press, New York, 1985, pp. 95-130.

8) C. Saccone, M. Attimonelli, and E. Sbiza: Structural elements highly preserved during the evolution of the D-Ioop-containing region in vertebrate mitochondorial DNA. J. Mol. Evol., 26, 205-211 (1987).

9) E. M. Prager, R. D. Sage, U. Gyllensten, W. K. Thomas, R. Hübner, C. S. Jones, L. Noble, J. B. Searle, and A. C. Wilson: Mitochondrial DNA sequence diversity and the colonization of Scandinavia by house mice from East Holstein. Biol. J. Linn. Sci., 50, 85-122 (1993)

10) W.-J. Lee, J. Conroy, W. H. Howell, and T. D. Kocher: Structure and evolution of teleost mitochondrial control regions. J. Mol. Evol., 41, 54-66 (1995).

11) A. Fajen and F. Breden: Mitochondrial DNA sequence variation among wild populations of Trinidad Guppy, Poecilia reticulata. Evolution, 46, 1457-1465 (1992).

12) L. K. Park, A. B. Mary, D. A. Dightman, and G. A. Winans: Low levels of intraspecific variation in the mitochondrial DNA of chum salmon (Oncorhynchus keta). Mol. Mar. Biol. Biotech., 2, 362-370 (1993).

13) T. D. Kocher, W. K. Thomas, A. Meyer, S. V. Edwards, S. Pääbo, F, X. Villablanca, and A. C. Wilson: Dynamics of mitochondrial DNA in animals: amprification and sequencing with conserved primers. Proc. Natl. Acad. Sci. USA, 86, 6196-6200 (1989).

14) T. Barry and F. Gannon: Direct genomic amplification autoclaved infectious microorganismus using PCR technology. PCR, Methods and Applications, 1, 75 (1991).

15) P.S. Walsh, D. A. Metzger, and R. Higuchi: Chelex 100 as a medium for simple extraction of DNA for PCR-based typing from forensic material. BioTechniques, 10, 506-513 (1991).

16) T. D. Kocher, J. A. Conroy, K. R. McKaye, and J. R. Stauffer: Similar morphologies of cichlid fish in Lakes Tanganyika and Malawi are due to convergence. Mol. Phyl. Evol., 2, 158-165 (1993).

17) A. Meyer, T. D. Kocher, Pereti Basasibwaki, and A. C. Wilson:
Monophyletic origin of Lake Victoria cichlid fishes suggested by mitochondrial DNA sequences. Nature, 347, 550-553 (1990).

18) Y. Chang, F. Huang and T. Lo: The complete nucleotide sequence and gene organization of carp (Cyprinus carpio) mitocondrial DNA gene. J. Mol. Evol., 38, 138-155 (1994)

19) D. L. Swofford: PAUP: Phylogenetic Analysis using Parsimony, Vrersion 3.0S, Illinois Natural History Survey, Champaign, Il linois, 1992.

20) M. Nei: Molecular Evolutionary Genetics, (Translated from English by T. Gojobori and N. Saitou), Columbia University Press, New York, 1987, pp. 218 -231.

21) N. Bowers, J. R. Stauffer, and T. D. Kocher. Intra and Inter specific mitochondrial DNA variation within two species of RockDwelling cichlids (Teleostei: Cichlidae) from Lake Malawi, Africa. Mol. Phyl. Evol., 3, 75-82 (1994).

22) A. Meyer, and A. C. Wilson: Origin of tetrapods inferred from their mitochondrial DNA affiliation to lungfish. $J$. Mol. Evol., 31, 359-364 (1990)

23) B. B. Normak, A. R. McCune, and R. G. Harrison: Phylogenetic relationships of Neopterigian fishes, inferred from mitochondrial DNA sequences. Mol. Biol. Evol., 8, 819-834 (1991).

24) J. Adachi, Y, Cao, and M. Hasegawa: Tempo and mode of mitochondrial DNA evolution in vertebrates at the amino acid sequence revel: Rapid evolution in warm-brooded vertebrates, $J$. Mol. Evol., 36, 270-281 (1993).

25) P. Cantatore, M. Roberti, G. Pesole, A. Ludovico, F. Milella, M N. Gadaleta, and C. Saccone: Evolutionary analysis of cytochrome b sequences in some perciformes: Evidence for a slower rate of evolution than in mammals. J. Mol. Evol., 39, 589-597 (1994).

26) W. K. Thomas, S. Pääbo, F, X. Villablanca, and A. C Wilson: Spatial and temporal continuity of kangaroo rat populations shown by sequencing mitochondrial DNA from museum specimens. J. Mol. Evol., 31, 101-112 (1990).

27) A. Di Rienzo and A. C. Wilson: Branching pattern in the evolutionary tree for human mitochondrial DNA. Proc Natl. Acad. Sci. USA, 88, 1597-1601 (1991).

28) M. Saitoh, M. Tanaka, R. Ueshima, T. Kamaishi, T. Kobayashi, and $K$. Numachi: Preliminary data on restriction mapping and Detection of length variation in Japanese flounder mitochondrial DNA. Aquaculture, 136, 109-116 (1995).

29) K. Kato, W. Anzawa, and K. Nashida: Study on resources management of flounder (Paralichthys olivaceus) in the northern coast of Nigata. II. Migration of an immature flounder and its Maturity and growth. Bull. Niigata Pre. Exp. Sta., 12, $42-59$ (1987).

30) T. Minami: Early life history of flatfishes-V. Duration of pelagic phase. Aquabiology, 5, 450-453 (1984).

31) T. Seikai, J. B. Tanangonan and M. Tanaka: Temperature influence on larval growth and metamorphosis of the Japanese flounder Paralichthys olivaceus in the laboratory. Nippon Suisan Gakkaishi, 52, 977-982 (1986). 